\section{Pilkada Bekasi Dalam Dilema \\ Patron Klien: Antara Sosiologi Politik Dan Pemilih Rasional}

\author{
Gilang Ramadhan \\ Program Studi Ilmu Pemerintahan, \\ Universitas Sultan Ageng Tirtayasa, \\ Indonesia. \\ *Korespondensi Penulis. E-mail: \\ gil.pas2000@gmail.com
}

\begin{abstract}
Abstrak
Berlangsungnya pemilihan langsung kepala daerah di Indonesia masih meninggalkan persoalan yang rumit, diantaranya masih maraknya dinamika patron-klien dalam pemilihan yang didasari oleh transaksi dan jaringan kuasa yang dibangun oleh pemilih dan calon, peneliti ingin meneliti dinamika patron-klien yang terjadi pada pemilihan kepala daerah Kabupaten Bekasi. Penelitian ini menggunakan pendekatan kualitatif dengan metode deskriptif untuk menggambarkan karakteristik pemilih serta faktor-faktor yang mempengaruhi perilaku pemilih pada Pilkada Kabupaten Bekasi. Hasil penelitian yang didapatkan adalah hubungan calon dengan pemilih dibangun atas dasar ketidaksamaan dimana calon merawat suara dengan material yg diberikan, disamping itu calon juga memanfaatkan pelapisan kekayaan dan jejaring pada kelompok tani. Hal ini juga membantah teori sosiologi politik, yang ternyata tidak berlaku pada masyarakat Kabupaten Bekasi.
\end{abstract}

Kata kunci: Patron-Klien, Perilaku Pemilih, Sosiologi Politik

\section{Bekasi Election in Client Patron's Dilemma: Between Political Sociology and Rational Voters}

\begin{abstract}
The ongoing direct election of regional leaders in Indonesia still leaves complicated issues, including the still rampant patronclient dynamics in elections based on transactions and power networking conducted by voters and candidates, researchers want to examine the patronclient dynamics that occur in the Bekasi District elections. This study uses a qualitative approach with descriptive methods to describe the characteristics of voters and the factors that influence voter behavior in Bekasi District Election. The research results obtained are relationship between voters and candidate built on inequality where candidate treat the votes with materials, besides candidates making use of wealth coating and network among group of rarmers. It also refutes the theory of political sociology, which apparently does not apply to the people of Bekasi Regency.
\end{abstract}

Keywords: patron-client, voters behavior, sociology politics 


\section{A. PENDAHULUAN}

Sejak terbukanya keran demokratisasi di Indonesia lewat reformasi tahun 1998, Indonesia mulai mengenal pemilihan langsung. Pemilihan langsung dilangsungkan di Indonesia pada tahun 2004 dimana masyarakat Indonesia memilih wakilnya di parlemen sekaligus memilih presidennya secara langsung. Hal yang tidak pernah terjadi saat orde baru berkuasa yang membawa dampak arus demokratisasi ke pelosok-pelosok daerah di Indonesia.

Namun, legacy orde baru yang berlangsung selama 32 tahun tidak serta merta menghilang dengan adanya reformasi tahun 1998 dan pemilihan langsung tahun 2004 terhadap sistem sosial masyarakat Indonesia yang sangat patronase atau istilah yang sangat umum di era orde baru adalah asal bapak senang (ABS). Banyak orang yang menganggap istilah patron-klien sebagai suatu kesamaan, tetapi itu memiliki makna yang berbeda (Edward, 2013), patronase berasal dari sumber daya material yaitu masyarakat menimbang aspek keuntungan dan kerugian untuk mendukung suatu partai politik atau figur seseorang, sedangkan clientelisme berasal dari aspek relasi kekuasaan seseorang yang memiliki ciri sebagai berikut : patron (status sosial yang lebih tinggi) berjejaring dengan klien (status yang lebih rendah), face to face dan saling melakukan hubungan timbal balik, dapat bervariasi dalam konten, tujuan, dan petunjuknya seiring dengan waktu.
Demokrasi di negara-negara Asia selatan khususnya Indonesia memiliki tantangan yang sangat berat dari masih banyaknya ketidaksetaraan (inequality) kedudukan dalam demokrasi yang diantaranya disebabkan masih kentalnya budaya patronase dan klientelisme. Ada beberapa contoh istilah yang serupa dengan patron-klien dari segi penerapannya di lapangan di negara Asia Tenggara, di Filipina dikenal sebagai klan dan bossism, di Thailand dikenal dengan istilah vote canvassers dan broker jaringan, dan bahkan di Malaysia justru partai politik yang menjadi patron di sana.(Edward, 2013)

Patron-klien di Indonesia dalam demokrasi sangat kental dirasakan saat pemilihan umum, baik di tingkat lokal (pilkada) maupun di tingkat nasional (pemilu). Pola patron-klien selain membawa efek buruk terhadap pemilih itu juga berpengaruh terhadap kinerja di dalam tubuh parpol atau kandidat itu sendiri. Di dalam struktur tim sukses suatu parpol atau kandidat terdapat banyak orang yang bergabung dengan motivasi yang berbeda, ada individu yang tergabung karena aspek kedekatan dengan kandidat atau parpol tertentu (activist brokers), ada individu yang tergabung karena semata-mata untuk mencari materi atau motivasi mencari kerja (clientelist brokers), dan yang terakhir untuk mencari materi dalam konteks jangka pendek (opportunist brokers).

Ketiga motivasi individu untuk terlibat di dalam struktur parpol atau 
kandidat di atas memiliki konsekuensi terjadinya semacam pengutipan atau perampokan (predation) seperti banyak kasus kandidat memberikan sejumlah uang untuk menghidupi mesin partai juga tim suksesnya, tetapi banyak pengutipan-pengutipan yang terjadi di lapangan oleh broker-broker sehingga uang yang diperuntukkan untuk kepentingan kampanye tadi tidak sampai untuk tujuannya, selain terjadinya pengutipan/perampokan juga sangat rentan terjadinya pengkhianatan (defection), seseorang yang bergabung dalam suatu struktur tim sukses parpol atau kandidat yang didasari oleh kepentingan materi sangat rentan untuk mencari materi yang lebih besar, sehingga jika individu tersebut menemukan yang lebih besar maka, parpol atau kandidat yang sedang diusungnya akan ditinggalkan dan beralih kepada parpol atau kandidat yang memiliki materi (dana) yang lebih besar.

Selain berpengaruh terhadap parpol atau kandidat, secara lebih besar pola patron-klien sebenarnya berdampak buruk bagi masyarakat pemilih itu sendiri. Karena kandidat yang memiliki materi lebih banyak mampu untuk membeli suara pemilih sehingga pemilih yang memilihnya memenangkannya dan kandidat tersebut tentu mendapat legitimasi dari pemilihan langsung tersebut, legitimasi yang didapat dari membeli suara memungkinkan kandidat tidak wajib untuk memberikan akuntabilitas (mengartikulasikan

dan mengagregasikan kepentingan rakyat kepada kebijakan publik), kemudian terputusnya relasi antara pejabat publik dan rakyat setelah pemilu berakhir dan terputusnya relasi tersebut berimplikasi terputusnya relasi kebijakan publik dengan rakyat sehingga kebijakan yang terjadi adalah kebijakan yang bias elit.(Edward, 2013)

Pola patron-klien secara kontekstual telah meruntuhkan teori sosiologis, seperti penelitian Ansyari, dkk. (Ansyari, 2019) yang meneliti suara partai Golkar pada pemilihan legislatif di Kabupaten Tanah Datar. Secara sosiologis Kabupaten Tanah Datar didominasi oleh agama islam yang masyarakatnya sangat religius, selain itu corak kebudayaan masyarakat juga kental dipengaruhi oleh ajaran islam. Partai Golkar yang memiliki ideologi nasionalis nyatanya mampu meraup suara yang besar di kabupaten ini bahkan mengalahkan partai-partai yang berideologi islam. Partai golkar dapat memelihara suara karena selain memiliki jejaring sayap-sayap partai seperti kelompok tani, angkatan muda, dan adat. Partai ini juga menjaga relasi patron klien dengan memanfaatkan pelapisan status social yang ada pada Kabupaten Tanah Datar yang masih sangat kental. Orang yang bergelar Datuak atau Ninik Mamak adalah orang yang disegani dan memiliki suara di dalam lembaga Kerapatan Adat Nagari (KAN) yang memiliki andil yang besar dalam pemilihan ketua adat, dan partai 
Golkar memiliki afiliasi yang kuat pada Datuak atau Ninik Mamak tersebut.

Pada masyarakat yang masih dikuasai oleh dominasi kultur, tentu saja aspek pemilih rasional (rational choice) dalam masyarakat masih belum menjadi pilihan, pendekatan yang sering digunakan dalam masyarakat yang didominasi kultur adalah pendekatan sosiologis atau sosio kultural. Kabupaten Bekasi sebagai lokasi yang ingin penulis bahas merupakan daerah pinggiran kota Jakarta yang mayoritas penduduknya merupakan suku Betawi, Suku Betawi yang menetap di pinggiran kota terkenal sangat religius dan banyak terpengaruh oleh patron keagamaan yaitu sosok Kiai atau pemuka agama. Pada penelitian ini peneliti ingin mengemukakan sejauh mana pengaruh pola patron-klien pada masyarakat Betawi Pinggir yang menetap di Bekasi dalam Pemilihan Bupati (Pilbup) Bekasi Tahun 2012.

\section{B. TEORI (Literature Review)}

Ada beberapa perspektif yang digunakan untuk meminimalisasi kuatnya pola patron-klien, diantaranya adalah pendekatan sosiologis atau sosial struktural. Pada pendekatan ini dibagi menjadi dua model penjelasan yaitu model penjelasan mikrososiologis dan makroosiologis. Dasar model penjelasan mikrososiologis berasal dari teori lingkaran sosial yang menjelaskan bahwa setiap manusia terikat dalam berbagai lingkaran sosial, contohnya keluarga, lingkaran rekan-rekan, tempat kerja dan sebagainya. Lazarsfed menerapkan cara berpikir ini kepada para pemilih. Seorang pemilih hidup dalam konteks tertentu: status ekonominya, agamanya, tempat tinggalnya, tempat kerjanya dan usianya mendefinisikan lingkaran sosial yang mempengaruhi keputusan pemilih. (Dioter, 2008)

Model penjelasan makrososiologis menurut Lipset dan Rokan mengacu kepada konflik-konflik mendasar yang biasa muncul di masyarakat, yang kesetimbangannya perlu dipertahankan dalam sebuah demokrasi. Para penulis mengacu pada klasifikasi sistem sosial Parson dimana sistem-sistem kemasyarakatan memiliki dimensi fungsional dan teritorial. Pada poros teritorial, negara (pusat) dihadapkan dengan daerah (bidang pinggiran/ perifer). Poros fungsional dibentuk oleh ekonomi di satu sisi dan ideologi di sisi lainnya. Konflik stereotip ideal menurut model ini adalah konflik mengenai kontrol atas sistem politis pada sisi atas poros teritorial, oposisi lokal melawan elit nasional yang dominan di sisi bawah poros teritorial, konflik ekonomi berkenaan dengan sumber daya, produksi dan laba di sisi kiri poros fungsional, serta konflik kawan-lawan pada sisi kanan poros fungsional (Dioter, 2008).

Pendekatan yang kedua adalah pendekatan sosial psikologis, menurut pendekatan ini persepsi dan penilaian pribadi terhadap sang kandidat atau tema-tema yang diangkat (pengaruh 
jangka pendek) sangat berpengaruh terhadap pilihan pemilu yang dijatuhkan. Selain itu, "keanggotaan psikologis" dalam sebuah partai yang dapat diukur dalam bentuk variabel identifikasi partai, turut mempengaruhi pilihan pemilu, hal mana merupakan hasil berbagai pengaruh jangka panjang. Oleh karena itu keputusan pemilu masing-masing individu secara primer tidak ditentukan secara sosial struktural, melainkan lebih merupakan hasil pengaruh jangka pendek dan jangka panjang terhadap individu.

Pendekatan sosial psikologis berusaha untuk menerangkan faktorfaktor apa saja yang mempengaruhi keputusan pemilu jangka pendek atau keputusan yang diambil dalam waktu yang singkat. Hal ini berusaha dijelaskan melalui trias determinan, yakni identifikasi partai, orientasi kandidat dan orientasi isu/tema. Sementara itu faktor-faktor lainnya yang sudah ada terlebih dahulu (seperti misalnya keanggotaan dalam kelompok sosial tertentu) dianggap memberi pengaruh langsung terhadap perilaku pemilih. Inti dasar pemikiran ini dituangkan dalam bentuk sebuah variabel yakni identivikasi partai (party identification /selanjutnya disingkat PI). Variabel ini digunakan untuk mengukur jumlah faktor-faktor predisposisi pribadi maupun politik yang relevan bagi seorang individu. Campbell et.al mengungkapkan apabila faktor-faktor predisposisi (seperti misalnya pengalaman pribadi atau orientasi politik) diumpamakan sebagai suatu aliran yang dituangkan melewati sebuah corong, maka PI yang merupakan semacam keanggotaan psikologi partai, dapat diumpamakan sebagai sebuah saringan dalam corong kausal ini (funnel of causality). (Dioter, 2008)

Dalam pandangan pendekatan rational-choice bahwa perilaku pemilih yang rasional terletak pada perhitungan biaya dan manfaat (cost and benefit). Menurut pendekatan rational choice, yang menentukan dalam sebuah pemilu bukanlah adanya ketergantungan terhadap ikatan sosial struktural atau ikatan partai yang kuat, melainkan hasil penilaian rasional dari warga yang cakap. Pada awal tahun enam puluhan, V.O Key menuding bahwa kedua pendekatan untuk menerangkan perilaku pemilu yang selama ini berlaku, merendahkan rasionalitas manusia.

Menurut Key, masing-masing pemilih menetapkan pilihannya secara retrospektif, yaitu dengan menilai apakah kinerja partai yang menjalankan pemerintahan pada periode legislatif terakhir sudah baik bagi dirinya sendiri dan bagi negara, atau justru sebaliknya. Penilaian itu juga dipengaruhi oleh penilaian terhadap pemerintah di masa yang lampau. Apabila hasil penilaian kinerja pemerintah yang berkuasa (juga bila dibandingkan dengan pendahulunya) positif, maka mereka akan dipilih kembali. Key menilai apabila hasil penilaiannya negatif, maka pemerintahan tersebut tidak akan 
dipilih kembali. (Maxwell \& Shield, 2011).

Keputusan pemilu sang pemilih yang rasional senantiasa berorientasi kepada hasil yang dicapai partai atau kandidat tertentu dalam politik, baik hasil yang dipersepsikan maupun yang diantisipasi. Apabila dalam model Key, yang menentukan keputusan pemilu hanyalah jumlah semua prestasi yang dicapai pemerintah, maka model-model berikut dibedakan berdasarkan masingmasing bidang politik (Gary Jocobson, 2020). Dengan demikian, maka modelmodel yang disebutkan terekhir dapat dipahami sebagai perkembangan spesifik lebih lanjut dari sebuah cabang pendekatan sosial psikologis, yakni orientasi isu dan penilaian terhadap kompotensi masing-masing partai dan kandidat dalam memecahkan permasalahan. Namun cakupan pembatasan terhadap issue voting dalam masing-masing model perilaku pemiluyang rasional senantiasa berbeda-beda.

Namun belakangan ini pemilih rasional kini mengalami pergeseran makna dari pemilih yang menyadari kebutuhan kepentingannya sehingga memilih partai politik atau kandidat yang memiliki kemungkinan paling besar untuk memenuhi kepentingan dari pemilih tersebut menjadi pemilih yang memilih parpol atau kandidat yang bisa memberi banyak materi dan sesegera mungkin (Sukmajati, 2013). Masyarakat kini mulai mencari kandidat atau parpol yang memiliki dana besar yang sanggup untuk memberikan mereka materi dalam waktu yang singkat, masyarakat tidak lagi memilih berdasarkan kesamaan ideologi dengan parpol atau individu, atau bergabung menjadi suatu partisan (memilih berdasarkan identifikasi kepartaian) dalam suatu parpol tertentu.

Dari beberapa pendekatan perspektif pemilih dalam menentukan suatu keputusan politik yang penulis utarakan, dalam hal kasus di Bekasi penulis ingin menggunakan perspektif sosiologi khususnya sosiologi politik untuk membaca peristiwa politik yang terjadi di sana. Penulis beranggapan bahwa lingkungan sosiologis khususnya organisasi keagamaan masih sangat kental di daerah yang berpenduduk mayoritas Betawi pinggiran. Masyarakat Betawi yang tinggal di pinggiran kota Jakarta disebut sebagai Betawi pinggiran atau Betawi pinggir yang dalam kehidupan sosialnya masih kental dipengaruhi oleh norma-norma keagamaan.

Sosiologi politik disini merupakan konsepsi keilmuan yang membahas tentang kekuasaan, pemerintahan, otoritas ataupun komando dalam struktur masyarakat. Baik itu dalam ranah lokal maupun nasional. Konsepsi Maurice Duverger dalam karyanya ini dilandasi oleg gagasan Leon Daguit, seorang ilmuan hukum perancis, dimana konsepsi sosiologi politik terbangun dengan adanya perbedaan antara yang 
memerintah (gouvernants) dan yang diperintah (gouvernes). (Duverger, 2013)

Sosiologi politik tersebut dengan sendirinya mempercayai bahwa dalam setiap kelompok manusia dari yang terkecil sampai dengan yang terbesar, dari sikapnya sekejap maupun yang stabil, ada orang yang memerintah dan mereka yang mematuhi perintah tersebut. Perbedaan ini merupakan fakta politik yang fundamental dalam setiap struktur masyarakat dan pada tiap tingkatan sosialnya. (Duverger, 2013)

Pada ranah partisipasi politik, sosiologsm approach menempatkan kegiatan memilih dalam kaitannya dalam konteks kontruksi sosiologi masyarakat, dimana perilaku seseorang dalam kasus patron-klien di Bekasi ini akan terlihat dari pengaruh latar belakang sosiologis mereka. Sikap individu memegang peranan dalam menentukan perilaku seseorang di lingkungannya, dimana lingkungan secara timbal-balik akan mempengaruhi sikap dan perilaku dengan berbagai faktor dan akan membentuk suatu proses kompleks yang menentukan bentuk perilaku seseorang. (Azwar, 2013) Untuk itu pengelompokan sosial di institusi keagamaan semisal di persyarikatan Muhammadiyah, Nahdatul Ulama (NU) dengan institusi pondok pasantrennya merupakan sesuatu yang vital dengan sosiologi politik.

Struktur sosial kemasyarakatan dengan dinamika institusi keagamaannya, kyai atau tokoh agama memiliki pengaruh yang signifikan. Pengaruh kyai atau elit keagamaan ditengah masyarakat ini menurut Sunyoto Usman dibedakan menjadi dua jenis kepimimpinan ; yaitu monomorphic dan polimorphic. Dimensi pengaruh ini berkaitan dengan struktur kekuasaan yang berkembang dalam kehidupan masyarakat yang berstruktur kekuasan pluralistik. Sehingga corak kepemimpinan yang bersangkutan hanya berpengaruh pada satu bidang saja. Sedangkan kepemimpinan yang bersifat polymorphic, lebih banyak ditemukan dalam kehidupan masyarakat yang pola struktur kekuasannya monolitik. Sehingga banyak ditemukan pola kepemimpinan polymorphic memiliki pengaruh dalam berbagai bidang sekaligus. (Sunyoto Usman, 2014)

\section{METODE}

Penelitian ini menggunakan pendekatan Kualitatif dengan metode deskriptif. Pendekatan kualitatif diperlukan untuk dapat menggali fenomena dan dinamika sosial kemudian data dianalisis secara induktif mulai dari mengupas bagaimana struktur sosial masyarakat betawi pinggir di Kabupaten Bekasi yang bersifat khusus hingga ke permasalahan yang sifatnya umum seperti bagaimana struktur sosial masyarakat betawi pinggir dapat mempengaruhi referensi memilih mereka atau ada faktor lain yang dapat mempengaruhi pemilih, 
serta upaya penulis untuk menafsirkan setiap data yang didapatkan.

Pengambilan data dilakukan dengan metode wawancara dengan masyarakat betawi pinggir Kabupaten Bekasi yang menjadi konstituen pada pilkada Kabupaten Bekasi 2012 dan 2017. Agar data yang didapatkan lebih lengkap dan menyeluruh, metode observasi juga digunakan dalam penelitian ini. Informan yang dipilih harus memiliki kualifikasi yaitu menguasai data, informasi atau fakta dari suatu objek penelitian (Bungin, 2015).

Triangulasi dilakukan untuk menguji keabsahan data, data yang didapatkan akan dikomparasikan dengan data lain sebagai pembanding seperti hasil dokumentasi, penelitian lain dengan tema yang sama, serta teori lain yang relevan dengan penelitian ini.

\section{HASIL DAN PEMBAHASAN}

\section{Suku Betawi Bekasi dan Patron- Klien}

Suku Betawi merupakan salah satu suku yang menetap di Jakarta dan kota-kota yang berada di sekitarnya yaitu Tangerang, Depok, Bogor, dan Bekasi, berdasarkan klasifikasinya suku Betawi dapat dibedakan menjadi tiga, yaitu Betawi Tengah, Betawi Udik dan Betawi Pinggir. Betawi tengah adalah penduduk Betawi yang bermukim di daerah kota, sebagian dari mereka masih menganut pola gaya hidup tempo dulu seperti resepsi perkawinan, lebaran, khitanan, maupun dalam kehidupan bersosialisasi masyarakatnya. Berdasarkan tingkatan ekonomi, orang Betawi yang tinggal di tengah-tengah kota Jakarta dibedakan menjadi orang gedong dan orang kampung. Orang gedong dianggap tidak merepresentasikan keBetawian mereka oleh orang kampung, sedangkan orang kampung dianggap kehadiran mereka sebagai orang kampung merupakan suatu tradisi.

Yang kedua adalah Betawi Pinggir, adalah penduduk Betawi yang bermukim di pinggiran kota Jakarta. Sebenarnya mereka adalah berasal dari Betawi tengah yang terkena dampak arus modernisasi dan urbanisasi sehingga terusir dari tengah kota ke pinggir kota karena mereka menjual tanah mereka di kota dengan harga mahal dan membeli tanah di pinggiran kota dengan harga yang murah. Jika Betawi tengah sangat superior dalam arti di dalam latar belakang sosial ekonomi dari kelompok Betawi yang lain, sedangkan Betawi pinggir dikenal sebagai paling superior dalam pendidikan agama dari kelompok Betawi yang lain. Orang Betawi Pinggir menyekolahkan anak-anaknya ke pesantren sebagai pendidikan formal mereka. Itu sebabnya orang Betawi menolak bila mereka dianggap tertinggal dalam arti pendidikan bila dibandingkan dengan kelompok lainnya di Indonesia, yang benar adalah mereka mempunyai bentuk pendidikan yang berbeda dengan suku lainnya. 
Walaupun orang Betawi Tengah menempuh pendidikan formal di Sekolah Umum, pendidikan agama menurut mereka merupakan bagian yang sangat penting didalam kehidupan mereka. Proses bermasyarakat orang Betawi Tengah ini tidak dapat dipisahkan dari pola kehidupan beragama. Proses sosialisasi ini telah membentuk kehidupan ber agama sebagai bagian dari kehidupan mereka sehari-hari.

Yang terakhir adalah Betawi Udik, ada dua tipe Betawi Udik, yaitu mereka yang tinggal di daerah bagian Utara Jakarta dan bagian Barat Jakarta maupun Tangerang, mereka sangat dipengaruhi oleh kebudayaan Cina. Dan lainnya adalah mereka yang ditinggal di sebelah timur maupun di Selatan Jakarta, Bekasi dan Bogor yang sangat dipengaruhi oleh kebudayaan Sunda. Mereka umumnya berasal dari kelas ekonomi bawah yang pada umumnya lebih bertumpu pada bidang pertanian. Taraf pendidikan mereka sangatlah rendah bila dibandingkan dengan tahap pendidikan yang dicapai oleh orang Betawi Tengah dan Betawi Pinggir.

Peran agama Islam dalam kehidupan sehari-hari orang Betawi Udik berbeda dengan peran agama Islam di antara orang Betawi Tengah dan Betawi Pinggir di mana pada kedua kelompok Betawi terakhir tersebut agama Islam memegang peran yang amat sangat penting dan menentukan dalam tingkah laku pola kehidupan mereka sehari-hari. Perlu dicatat bahwa kini telah terjadi perubahan dalam pekerjaan dan pendidikan di antara orang Betawi Udik di mana secara perlahan-lahan tingkat dan pola pekerjaan mereka mendekati pola pekerjaan dan pola pendidikan orang Betawi Tengah dan Betawi Pinggir.

Jika dilihat dari pola bagaimana Betawi Tengah, Pinggir dan Udik memiliki relasi yang kuat terhadap nilainilai religiusitas dan pola pendidikan dan mata pencaharian yang sudah relatif setara satu dengan lainnya maka konsekuensi dari sikap politik masyarakat betawi memiliki kesamaan diantara ketiganya. Yaitu dapat dimobilisasikan dalam relasi patronklien berdasarkan kepentingan mereka. Dalam penelitian Fadiyah dan Zakiyah menyebutkan bahwa setidaknya ada lima hubungan patron-klien yang terjadi antara masyarakat Betawi dengan calon gubernur DKI Jakarta, sehingga masyarakat Jakarta secara sukarela mau memberikan suaranya kepada calon tersebut. Diantaranya adalah (1) Sarana dasar subsistensi yaitu pola hubungan yg didasarkan jasa yang dapat dideliver oleh calon, (2) Jaminan krisis subsistensi yaitu calon dapat merawat keresahan yang menjadi permasalahan klien, (3) Perlindungan yaitu calon dapat menjamin keamanan dari klien, (4) Pengaruh, dan (5) Jasa koletif patron yaitu jaminan kesejahteraan kepada klien. (Dina, Fadiyah; Ummi, 2018) 


\section{Sosiologi Politik vs Kepentingan Ekonomi}

Daerah yang menjadi perhatian dalam tulisan ini adalah Kecamatan Tarumajaya, Kabupaten Bekasi yang mayoritas penduduknya merupakan suku Betawi. Dari klasifikasi suku Betawi yang dibahas sebelumnya, suku Betawi yang tinggal di Kecamatan Tarumajaya, Kabupaten Bekasi tergolong sebagai Betawi Pinggir yang tinggal persis di perbatasan dengan Jakarta. Kecamatan Tarumajaya dari pengamatan yang kami lihat di lapangan beberapa bagian terdiri dari perumahan elit di dalam komplek Kota Harapan Indah dan tentu saja kebanyakan yang tinggal di sini adalah pendatang dari Jakarta dan sekitarnya, dan ada beberapa bagian yang terdiri dari pemukiman-pemukiman kumuh yang rawan banjir.

Dari dua kelurahan yang penulis teliti dari kecamatan Tarumajaya, penelitian dilakukan pada bulan Desember 2012 bersama lembaga survey Charta Politika. Adalah bagian dari survei nasional pemilihan presiden yang diadakan selama kurun waktu 2012, kebanyakan masyarakat menganggap pentingnya agama dalam mengatur kehidupan mereka, dan kebanyakan dari mereka juga tergabung dalam organisasi keagamaan yaitu Nahdlatul Ulama (NU), kemudian data yang lain juga menyebutkan bahwa mereka sangat menghormati pemimpin atau pemuka agama yang ada di sana. Dari data-data yang disebutkan di atas tentu saja penulis beranggapan bahwa masyarakat Kecamatan Tarumajaya, Kabupaten Bekasi sangat dipengaruhi perspektif sosiologis dalam menentukan pilihan politiknya di dalam pemilihan umum, hal ini dapat dilihat apalagi patron mereka yaitu Kyai dan pemuka agama juga memiliki sumber daya materi yang mumpuni selain juga kemampuan kepemimpinan kharismatik yang mereka miliki. (Ramadhan, 2012)

Namun ada pertanyaan lain yang ternyata cukup mencengangkan hasilnya, ternyata masyarakat di sana dalam menentukan pilihan politiknya tidak harus sama dengan tokoh agama atau kyai di sana, mereka memang sangat menghormati sosok seorang Kyai atau tokoh agama yang mereka anggap sebagai pemimpin agama di dalam kehidupan sosial yang religius pada masyarakat Betawi Pinggir, tetapi mereka menganggap Kyai atau tokoh agama yang memasuki dunia politik akan menjadi kotor dan akan terlibat dalam korupsi, mereka menginginkan Kyai atau tokoh agama tetap mengurusi kepentingan agama dibandingkan mengurusi perpolitikan.

Pragmatisme sangat menonjol ketika masyarakat menjawab mereka akan mengambil uang dari money politics dan menganggap politik uang sebagai sesuatu yang lumrah bahkan sesuatu yang seharusnya diberikan oleh seorang calon pemimpin, namun masalah pilihan mereka belum tentu terpengaruh oleh pemberian uang tersebut menurut mereka. Masyarakat 
Kecamatan Tarumajaya, Kabupaten Bekasi justru sangat mengharapkan apabila datang seorang kandidat atau kampanye partai di daerahnya, maka kandidat atau partai tersebut akan membagi-bagikan uang. Mereka biasa menyebut uang politik uang tersebut dengan sebutan "uang es". Bahkan ekstrimnya apabila ada kandidat atau partai politik yang tidak membagibagikan uang saat datang ke daerah mereka maka masyarakat tidak akan menganggap kedatangan kandidat atau partai politik tertentu.

Pola patronase yang sangat didominasi oleh materi "uang" seperti ini tentu sangat tidak wajar apabila diterapkan di daerah yang menganut sistem sosial yang religius, dimana patron yang terjadi pada masyarakat tersebut seharusnya adalah pemimpin agama atau kyai. Namun yang terjadi pada masyarakat Betawi Pinggir yang tinggal di Kecamatan Tarumajaya, Kabupaten Bekasi sangat berbeda. Seharusnya jika sistem sosial religius dapat mempengaruhi keputusan memilih mereka, dimana kandidatkandidat yang berlatar belakang agama atau partai-partai agama seharusnya menang pada daerah yang bercorak seperti ini.

Dalam hal ini pendekatan perspektif sosiologi politik tidak berhasil untuk mengungkapkan bagaimana masyarakat yang struktur sosialnya religius malah justru mengedepankan aspek rasional dalam menimbang keputusan pilihan politik mereka, dimana dalam pandangan pendekatan rational-choice berpandangan bahwa perilaku pemilih yang rasional terletak pada perhitungan biaya dan manfaat (cost and benefit). Menurut pendekatan rational choice, yang menentukan dalam sebuah pemilu bukanlah adanya ketergantungan terhadap ikatan sosial struktural atau ikatan partai yang kuat, melainkan hasil penilaian rasional dari warga yang cakap. Pilihan rasional yang dimaksud disini adalah pilihan rasional yang telah bergeser maknanya menjadi perhitungan manfaat yang didapat dari kandidat atau parpol yang bisa diberikan dalam waktu yang singkat dan tidak memperhatikan aspek manfaat dalam jangka yang panjang.

Pemilih di Kecamatan Tarumanegara, Kabupaten Bekasi tidak memperdulikan lagi tata nilai yang ada di dalam lingkungan sosial mereka dalam memilih suatu Kandidat atau partai, tetapi memikirkan bagaimana mereka dapat memperoleh benefit dari partai atau kandidat dalam waktu yang singkat. Tentu saja patron yang berkuasa di sana adalah pengusaha yang memiliki dana banyak yang mampu untuk membeli suara dari masyarakat.

Hal ini dapat dilihat dari pemenang pemilihan Bupati Kabupaten Bekasi pada Tahun 2012, yang keluar sebagai pemenang adalah pasangan Nero atau Neneng Hasanah Yasin-Rohim Mintaredja yang diusung oleh partai Golkar dan Demokrat. Neneng berasal dari kalangan pengusaha yang tentu saja 
memiliki materi yang cukup untuk berkompetisi sebagai calon Bupati di Kabupaten Bekasi. Sebagai anak dari seorang pengusaha beras Neneng memiliki jejaring yang luas dari kelompok-kelompok tani yang ada di Bekasi, kelompok tani tersebut dijaga kebutuhannya seperti alokasi pupuk dan distribusi hasil pertanian termasuk lahan-lahan mereka yang tersebar luas yang disewakan untuk pertanian sehingga memiliki ketergantungan yang tinggi terhadap keluarga Neneng.

Dari beberapa warga yang kami wawancara partai pengusung NenengRohim sering ke daerah mereka dan sangat sering mengadakan acara yang ujung-ujungnya membagikan uang kepada masyarakat, tentu saja masyarakat senang karena partai pengusung Nero dianggap sangat dekat dengan rakyat dan mau membagi-bagi "uang es" kepada mereka, masyarakat tidak lagi mempedulikan seperti apa nanti pemimpin yang mereka pilih, mereka hanya berpikir bagaimana mereka mendapatkan uang di saat masa kampanye dan pada saat itu mereka dapat membeli kebutuhan pokok yang mereka butuhkan.

Dan kandidat terkuat (incumbent) yang kalah berasal dari partai yang berideologi agama yaitu PKS dan PPP. Pada pendekatan sosiologis, masyarakat yang menganut sistem sosial yang religi akan mempengaruhi keputusan pilihan politik anggota masyarakatnya sesuai dengan sistem sosial yang ada, tetapi dalam kasus ini partai yang berbasis agama yaitu PKS yang berasal dari Ikhwanul Muslimin dan organisasi keagamaan lain serta PPP yang berasal dari Nadlatul Ulama yang memiliki basis yang kuat di kalangan masyarakat Betawi Pinggir dan organisasi keagamaan lain tidak mampu melawan rasionalitas warga yang menginginkan kesejahteraan dalam waktu yang singkat, dalam penelitian penulis menyimpulkan bahwa masyarakat sudah terpatron pada figur yang memiliki sumber daya materi yang lebih menggiurkan ketimbang hanya memberikan janji saat kampanye.

Jika melihat pengakuan warga yang melihat partai politik pengusung Nero sering mengadakan acara seperti dangdutan di daerah mereka dan membagi-bagikan uang kepada mereka sangat sejalan dengan jawaban yang diberikan warga saat ditanyakan model kampanye yang paling efektif menurut mereka, mereka menjawab lebih suka kandidat atau partai yang turun ke masyarakat ketimbang dengan cara lain seperti beriklan di media cetak atau elektronik maupun dengan memasang spanduk di jalan. Menurut mereka, masyarakat selain membutuhkan materi yang dibagi-bagikan oleh kandidat atau parpol, mereka juga merasa terhibur dengan suguhan hajatan dangdutan yang diadakan oleh kandidat atau parpol tersebut. 


\section{E. SIMPULAN DAN SARAN}

\section{Simpulan}

Dari kasus yang penulis amati di atas dapat diambil kesimpulan bahwa tidak selamanya masyarakat yang menganut suatu sistem sosial tertentu dapat mempengaruhi pilihan politik dari individu-individu yang berada di dalam lingkaran kehidupan sosial tersebut. Ada hal-hal lain yang menjadi pertimbangan yang dapat mempengaruhi keputusan politik seseorang seperti faktor pemilih rasional, dimana dalam memutuskan suatu pilihan politik aspek keuntungan dan kerugian dipertimbangkan dan lebih baik lagi apabila dapat dirasakan dalam waktu yang relatif singkat. Masyarakat sudah tidak perduli pada seperti apa calon yang mereka pilih di kemudian hari asalkan pada saat kampanye mereka bisa mendapatkan keuntungan sebesar-besarnya sehingga yang disebut dengan penghianatan dan perampokan sangat terbuka sekali dan pada akhirnya masyarakat akan terputus relasinya dengan pemerintah dalam hal mengakses kebijakan publik.

Dalam kasus di Kecamatan Tarumanegara, Kabupaten Bekasi di saat lingkaran sosial yang religius sudah tidak bisa mempengaruhi keputusan politik anggota masyarakatnya pendekatan sosiologis, maka pendekatan pemilih rasional sangat tepat untuk menggambarkan pilihan warga yang ada di sana.

Namun aspek rasional choice sendiri pun mengalami pergeseran makna yang luar biasa, dimana perimbangan keuntungan yang akan didapat akan dirasakan dalam jangka panjang menjadi harus bisa diwujudkan dalam waktu yang relatif singkat. Tentu saja perspektif pilihan rasional menjadi mengalami perubahan makna menjadi buruk, yang sangat rentan terhadap money politics serta kecurangankecurangan lain yang dapat mencederai demokrasi itu sendiri, demokrasi yang seharusnya dapat membawa kesetaraan (equality) kedudukan di antara masyarakat malahan menimbulkan ketidaksetaraan (inequality) dimana masyarakat sangat senang dan sukarela untuk bertransaksi dalam pemilu dengan pola-pola patron-klien, masyarakat akan memberikan suara mereka kepada kandidat atau partai yang mampu untuk membayar mereka.

\section{Saran}

Pilihan rasional (rational choice) perlu lebih disosialisasikan lebih massif lagi terhadap warga, pendidikan pemilih diharapkan dapat digencarkan baik oleh partai politik maupun oleh penyelenggara pemilu seperti KPU dan BAWASLU sehingga penyimpangan makna keuntungan yang didapat dari memilih yang seharusnya dapat dirasakan selama lima tahun ke depan tidak terus menerus mengalami pejorasi makna yang dibelokkan menjadi menerima manfaat dari calon saat kampanye.

Demokrasi akan dapat berjalan secara baik apabila masing-masing warga memiliki kesetaraan (equality). Maka penyelenggara pemilu harus 
menyosialisasikan pemilu yang selain jujur dan adil tetapi juga setara. Kesetaraan tidak akan pernah terjadi jika masih ada mental patron klien antara calon dan pemilih, dan mental ini hanya bisa dirubah apabila warga menyadari bahwa mereka memiliki peran penting dalam membangun demokrasi dan Negara, dan peran mereka ada pada suara yang mereka berikan untuk memilih pemimpin lima tahun sekali.

\section{DAFTAR PUSTAKA}

Ansyari, I. (2019). Analisis Patron Klien Terhadap Kemenangan Partai Golkar Kabupaten Tanah Datar Sejak Reformasi.

Azwar, S. (2013). Sikap Manusia dan Pengukurannya. Yogyakarta: Pusat Belajar Offset.

Bungin, B. (2015). Penelitian Kualitatif. Jakarta: Kencana.

Dina, Fadiyah; Ummi, Z. (2018). Menguatnya Ikatan Patronase dalam Perpolitikan Indonesia. Journal Madani, 10(2), 75-88. https://doi.org/10.1017/CB09781 107415324.004
Dioter, R. (2008). Studi Pemilu Empiris: Sumber, Teori-teori, Instrumen dan Metode. Jakarta: FnsIndonesia.

Duverger, M. (2013). Sosiologi Politik. Jakarta: Rajawali Press.

Edward, A. (2013). Money Politics, Patronage, Political Networks, and Dynamics in Southeast Asia. Yogyakarta.

Gary Jocobson, J. L. C. (2020). The Politics of Congressional Elections. The Rowman \& Littlefield Publishing Group,Inc.

Maxwell, A., \& Shield, T. G. (2011). Unlocking V.O. Key Jr.: "Southern Politics" for the Twenty-First Century. The University of Arkansas Press.

Ramadhan, G. (2012). Survei Nasional Perilaku Pemilih 2012.

Sukmajati, M. (2013). Memilih yang Rasional. Yogyakarta.

Sunyoto Usman, D. (2014). Transformasi Demokrasi Indonesia Menuju Perubahan yang Bermakna. 3(2), 36-39. Retrieved from http://repositorio.unan.edu.ni/298 6/1/5624.pdf 